\title{
Biostatistics Core
}

National Cancer Institute

\section{Source}

National Cancer Institute. Biostatistics Core. NCI Thesaurus. Code C16044.

A shared facility providing biostatistical services. 